\title{
Distance Learning: Step by Step
}

\section{Richard D. Manning, Maxine S. Cohen, and Robert L. DeMichiell Nova Southeastern University Fort Lauderdale, Florida}

\section{manningr@nova.edu cohenm@nova.edu demichie@nova.edu \\ Executive Summary}

Distance learning is rapidly becoming pervasive in every aspect of education. From elementary school through doctoral programs, information technology enables self-paced learning with some degree of distance from teaching professionals. Educators sometimes begin this online delivery system without fully examining the academic soundness of this approach. Other considerations are administrative matters involving the hardware, software, and service needed to execute the methodology, and most importantly, the impact on the teachers, or facilitators. This paper presents a model of thinking and teaching styles and presents teaching strategies for the evolution from a basic to a complex learning scenario.

In discussing the ultimate transition from traditional to an online learning environment, the differences are highlighted. The following questions are raised at the outset and are addressed:

- Do you really want to teach online courses?

- If so, how do you move from a traditional style to the online style?

- Is this medium suited to your teaching style and your goals and objectives?

- Will students learn more effectively?

- What are the roles and commitments of faculty and students in this new learning scenario?

- What are the international and/or cross-cultural issues of online instruction?

Using Bloom's taxonomy for learning style and teaching strategies from traditional to online learning as the two dimensions, the paper discusses how a teacher can progress to advanced steps of the process. Starting with the traditional lecture/discussion method, moving to experiential learning techniques and case studies, and finally team teaching and distance education, the model discusses alternate progressions from structured learning (traditional/lower order thinking skills) to unstructured learning (online/teams/higher order thinking skills). Three pathways are delineated from which the teacher can enter at any point and progress to an advanced level.

After discussing each step of the process and the factors to be considered in moving from one level to another, following any of three pathways, the paper culminates with practical guidelines for the teacher

Material published as part of this journal, either on-line or in print, is copyrighted by the publisher of the Journal of Information Technology Education. Permission to make digital or paper copy of part or all of these works for personal or classroom use is granted without fee provided that the copies are not made or distributed for profit or commercial advantage AND that copies 1) bear this notice in full and 2) give the full citation on the first page. It is permissible to abstract these works so long as credit is given. To copy in all other cases or to republish or to post on a server or to redistribute to lists requires specific permission and payment of a fee. Contact Editor@JITE.org to request redistribution permission. contemplating transition from traditional to online teaching. In this way, the various tradeoffs of teaching style, course content, use of lecture, case and experiential techniques, and time necessary to prepare any new teaching delivery system can be evaluated at the outset. Such advance notice of the impact of major teaching style changes on the learning environment can prove to be invaluable for teachers, administrators, and learners. Teachers learn to adapt to new methods. Administrators 
are more aware of the resource requirements for such online methods. Students reap the benefit of appropriate information technology enablement for their learning process.

Keywords: Online teaching, distance education, Bloom's Taxonomy, learning styles, teaching styles, team teaching, higher education, information technology

\section{Introduction}

So you think you want to teach an online course? After four decades of teaching at the collegiate level, the authors have accumulated a multitude of experiences. Although the discipline of information systems has emerged as the major thrust of our academic expertise and teaching, mathematics, physical sciences, engineering, leadership, management, organizational development and behavior, and counseling psychology have also been contexts for teaching experiences. Earlier, different delivery systems were tried, starting with the traditional lecture/discussion method, moving to experiential learning techniques and case studies, and finally team teaching and distance education. These experiences included not only courses for all levels of undergraduate and graduate students in national and international scenarios, but also in teaching seminars to executives in government, business, and higher education..

Student learning objectives have driven the process, creating a learner-centered environment. If a new technology could motivate students to learn more effectively, it was used. If a new technique proved to be helpful, it was tried. If team teaching methods provided more points of view and stimulated discussion, we collaborated. However, for the online environment the situation changed dramatically. The startup time for such a venture was enormous. The obvious support of hardware, software and services (training) was needed to get the program off the ground.

Not so obvious was the inclination, or disinclination, of faculty to participate in an online program. Most faculty have taught their students face-to-face for years and developed a style which fit their personalities and contributed to the learning experience, such as the following:

- Use body language, voice inflection, etc. to emphasize comments,

- Relate anecdotes and personal experiences in the workplace,

- Meet with students informally before, during, and after class,

- Work with student teams onsite in business environments,

- Moderate guest lecturers with face-to-face discussion with students,

- Take students on trips to other countries for international experiences,

- Meet out of class with those students having difficulty with course material,

- Discuss aspects of the course that might be difficult in writing,

- Discuss personal/confidential student problems affecting course performance,

- Promote team participation and team communication, and,

- Coordinate team-teaching and other activities.

The loss of some of these attributes from the traditional face-to-face environment was not fully expected by the authors prior to the change to the online scenario. Are you ready to lose them? Chat rooms and other tools can minimize the loss and provide an alternative for some of these attributes that do not require physical presence. But will the academic climate be the same?

On the other hand, some apparent changes to an online methodology allow instructor and students to:

- Use technology for more convenience (more flexible ti me schedule),

- Emphasize content and not be distracted by personal issues,

- Communicate more frequently through email and chat rooms,

- Receive team and individual progress reports via email and chats,

- Be free from a classroom-intensive schedule, 
- Use the lost classroom time to conduct more research and project work,

- Place more of a burden on the student to comprehend the material, and,

- Place a burden on the instructor to prepare a more structured course.

Both of the above lists are not inclusive but merely show that reflection of the issues after the fact demonstrates that there is more to this transition from traditional to online teaching than is obvious. Before a model is introduced to describe the various scenarios of teaching and learning, which would enable the new or aspiring online teacher to approach such a commitment in a more comprehensive way, it is instructive to provide a brief overview of our journey from traditional to online (distance) teaching. In this way, the issues and problems are highlighted and form the basis for a more systematic view so that the reader can relate his or her situation to our experiences and then proceed to place oneself in a framework, or model, to decide:

- Do you really want to teach online courses?

- If so, how do you move from a traditional style to the online style?

- Is this medium suited to your teaching goals and objectives?

- Will students learn more effectively?

- What are the roles and commitments of faculty and students in this new process?

- What are the international and/or cross-cultural issues?

\section{Research Data}

A brief overview follows this segment with general comments derived from the authors' experiences in government, business, and education. Although some of this experience has resulted in presentations and publications, and is so noted here, there are other projects for which there is documentation that does not appear in the literature. Since such data is related to the generalizations in the remainder of this paper, it is necessary to include this data at this time in the form of selected research notes.

These selected research notes are listed separately from references at the end of the paper. They are organized by the framework of the six blocks (A through F) shown in Figure 1. In this way, the reader can become familiar with the data supporting each of these blocks as they make the transition from traditional teaching at the lower left corner of the diagram to teaching online at the upper right corner.

\section{Overview of Journey to Distance Learning}

Administrators welcome the idea of teaching in this new mode. More and more institutions are jumping on the distance education bandwagon (Hanna, 1998). The advantage to the university is that no classrooms are needed, fewer faculty offices are needed, and class scheduling is eliminated (Buckley, 2000). With technology in hand and a high profit margin expected, the promise of education at a distance is here and being expanded into international arenas (Barajas, 2002; Keyter, 2002; Merryfield, 2002). Lack of a distance education program today creates the impression the institution is not competitive. A full treatment of the administrative issues is beyond the scope of this paper.

The most unexpected result of our switch to the online environment was that it took much more time to prepare the course. Not only did the technology have to be ready and the instructor trained to use the technology, but also we had to devote much more time to course reorganization and adapt our well formed teaching styles to a new format (Dringus, 2000). Less face-to-face interaction took place but much more time needs to be allocated to being attached to the computer. Although it was more convenient, it was more intense. For example, we could sign on whenever and from wherever we wanted, but when we did, the amount of communications we received from the students could be overwhelming. 
FIGURE 1

Thinking Skills versus Teaching Styles

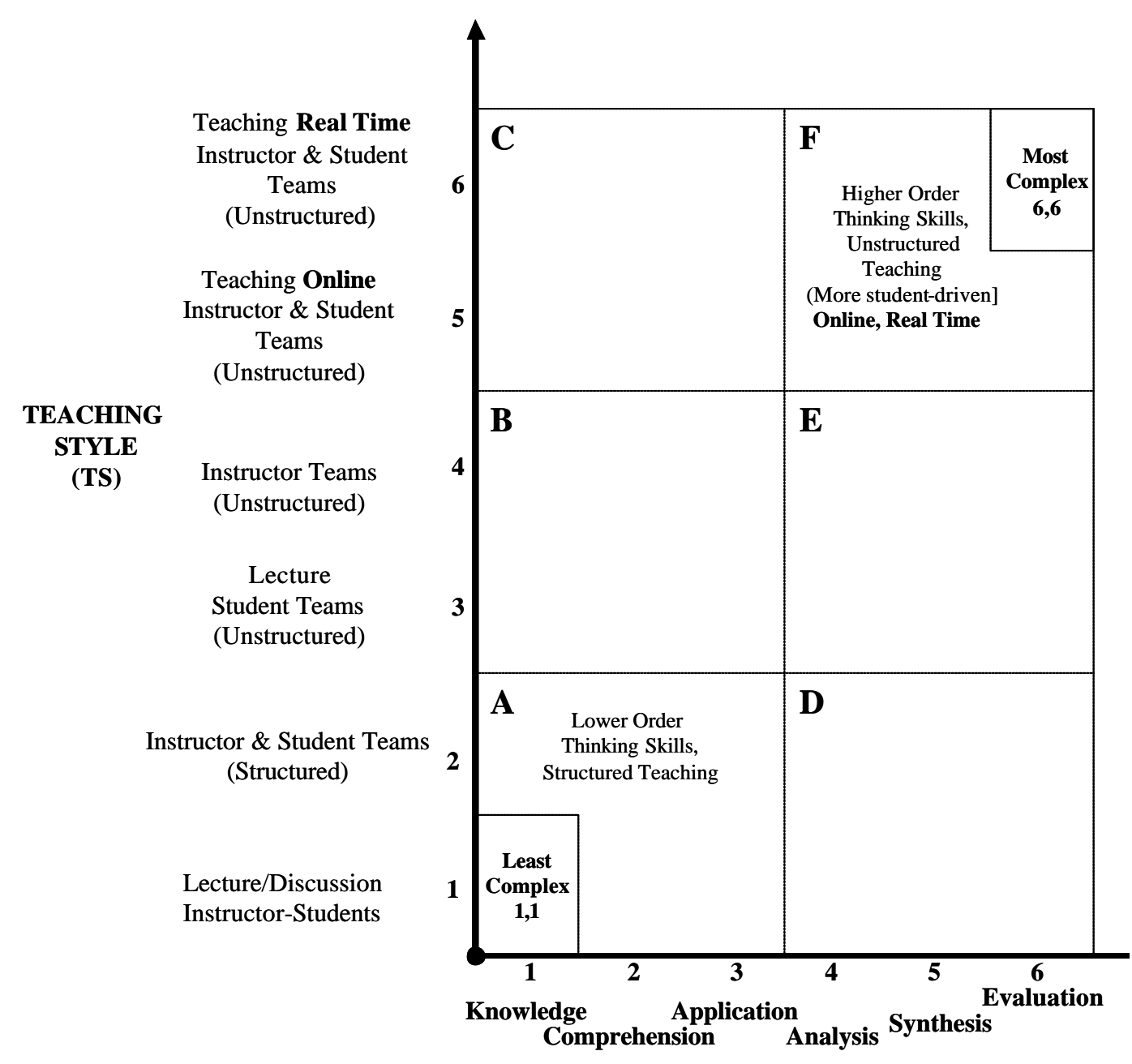

LEARNING (THINKING) SKILLS (LS)

[Bloom's Taxonomy]

In the beginning of our transition, we focused on a single instructor teaching a course through a commercially available computer system arranged by the university. No frills. No real time chat room sessions. No instructor teams, student teams, case studies, or experiential exercises. The experience was a learning one for both instructor and student. Lower order student thinking skills (lectures through electronic slides and texts, discussion, and some application of concepts) were used. The higher order skills (analysis, synthesis, and evaluation) would be examined with less rigor at this time, but would be addressed further in revisions to the course and as experience with the online medium grew. In addition, team teaching scenarios would be developed for the new online environment. A conservative approach to the methodology was taken. In hindsight, it was a good start.

The remainder of this article further outlines the opportunities and problems and provides some guidelines to walk this maze to create a quality educational experience to be enjoyed by faculty and students. By using a theoretical model and presenting several paths to accomplish the transition to online learning, an effective framework will be created. The purpose of the framework is to provide support and assis- 
tance to the instructor contemplating, being pressured, or already drowning in this new teaching environment. Research needs to be grounded in theory (Perraton, 2000; Berge, 2000).

\section{Theoretical Model for Assessment of Distance Learning}

The previous section outlined some of the pathways, problems, expectations, and procedures that could be followed in pursuit of distance learning education. However, it may not apply to your situation. Some type of framework is necessary to uncover the issues and allow feasible solutions for any such ventures. Bloom's taxonomy (Bloom, 1956) will be used as the framework. We mentioned the six categories of student thinking skill development in the previous section: knowledge, comprehension, application, analysis, synthesis, and evaluation. The progression from lower order thinking skills (the first three) to higher order thinking skills (the last three) serve as one direction of the student learning model. The other dimension is more of a teaching delivery system, starting with the traditional lecture/discussion mode of instructor-student interaction and progressing to online, real time interactions between instructor teams and student teams. Figure 1 depicts the resulting framework. You can see that the paradigm shift from the lowest to highest level may result in disaster. Some type of step progression is needed. Some awareness of where you are in terms of teaching style, your destination, and how to get there need to be evaluated before you take the journey.

It must be emphasized at the outset that all cells in Figure 1 are appropriate teaching styles and provide learning (thinking) skill development. It is not necessary that faculty move from a single position (even the lower-left cell). For some academic environments and courses, it may be appropriate to concentrate on the lecture/discussion method to facilitate learning. However, if one is interested in moving to the online scenario, there are many paths. There is no one path suggested for all individuals. Our experience indicates that a stepwise progression from the lower-left to the top-right is a safe journey. Large steps introduce too many new formats for students to assimilate while immersed in the content of the course. The format should not obscure the content but help to facilitate it. Information technology should be considered an "enabler" in this process (Harrison \& Bergen, 2000; Twigg, 1996). Online computing and increasing the distance between teacher and student requires some type of plan. This teaching-learning model captures one way of looking at the process and may be helpful in selfassessment and perhaps transition into the more complex online environment with emphasis on higher order thinking skills (DeMichiell \& Manning, 2002).

\section{Issues for Moving Into the Online Environment (Distance Learning)}

The ultimate goal of the framework is to facilitate the move from the lower-left corner to the upper-right corner of Figure 1. In order to get there, there are three different paths that can be taken. One path is no better than the other; they all have the same goals. Different types of obstacles and hazards can be found along the way. Understanding the terrain and the potholes can help make the trailblazing easier. It is not necessary to reach the top. Effective teaching and communication is difficult and succeeding at these aspects of learning alone is a big accomplishment. Some instructors may become comfortable at one of the steps along the way and might stay there or wait a while before moving on. Again, the purpose of this framework is to provide support for the journey.

Regardless of path chosen, transitions have to be made to cross the narrower border from left to right into higher order thinking skills or cross the wider borders involving the teacher's style into the unstructured formats and eventually to an online implementation. At any rate, preparing students for the world of work in a global marketplace dictates a fresh look at new learning experiences (Boisjoly \& DeMichiell, 1995). A step-wise progression is suggested. No matter which path you choose, it will involve the teacher's style and have tremendous impact on the student as well. The basic decisions are 
where to cross the borders. This research will present three possible paths to take and their implications for both instructor and learner. They will be presented in more detail in the next section.

\section{Transitioning to Online Learning, a Stepwise Approach}

\section{Learning Style Dimension: Crossing the Border into Higher Order Thinking Skills (Figure 2, "Over and Up")}

Educators strive to move students along the learning style dimension to higher order thinking skills. As students progress in age, experience, and academic background, it is more of a challenge to present yet another theory, concept, or application which will capture their imagination and motivate them to ana-

FIGURE 2

Learning Style Dimension Crossing the border into higher order thinking skills

(Over and Up)

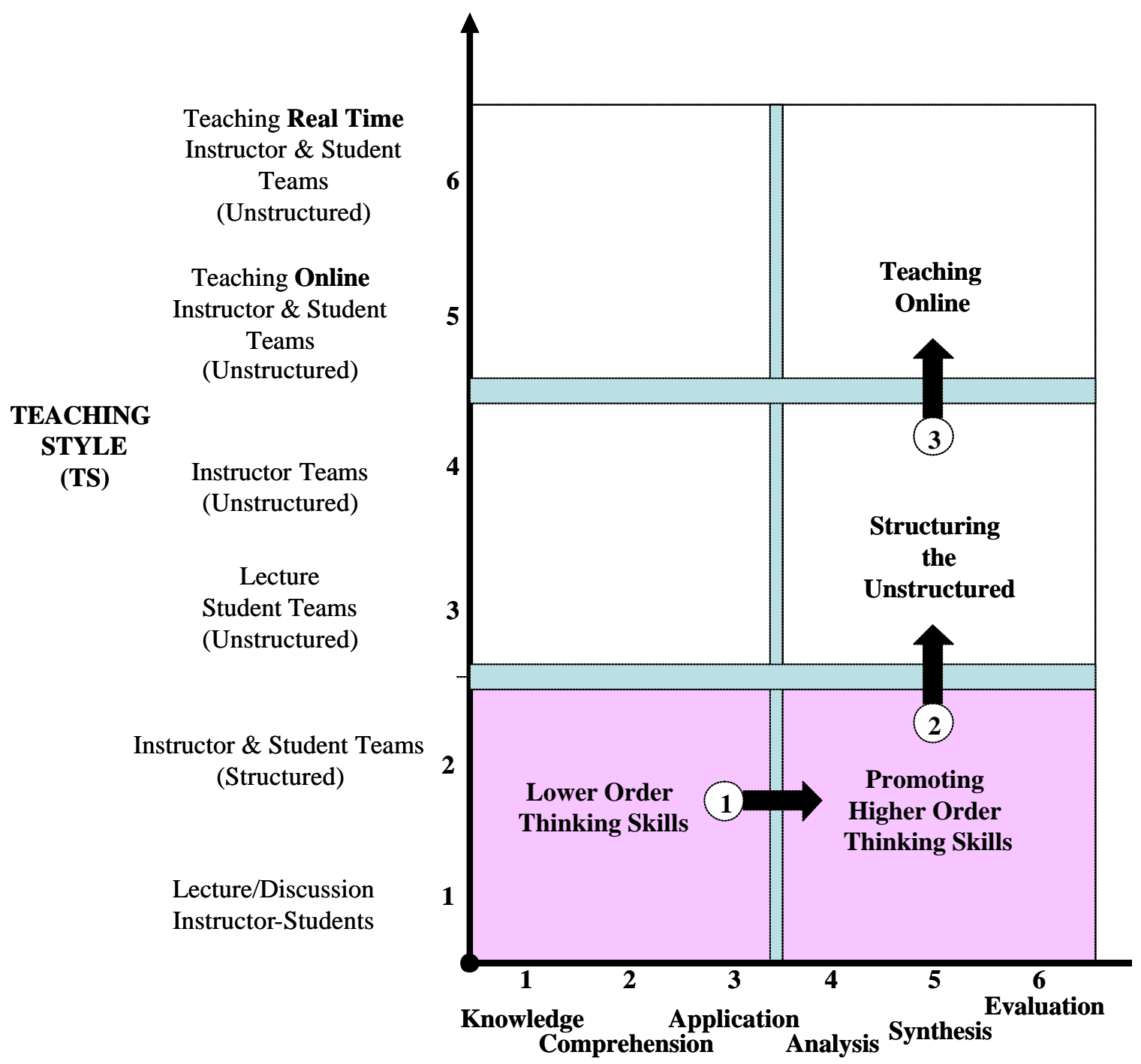

LEARNING (THINKING) SKILLS (LS)

[Bloom's Taxonomy] 
lyze, synthesize, and evaluate. The easy solution is to provide all the tools and methods to promote these skills (Figure 2, Step 1) and structure this activity so that the problem solving process is followed. Students like processes where everything is provided (Cohen \& Ellis, 2001; Hara \& Kling, 1999; Paloff $\&$ Pratt, 1999). They must put the given pieces together to produce a reasonable solution in a short and definite time frame and present the results in an analytical and evaluative manner. Also, many students prefer to work independently so there is minimum disruption to the process and little dependence on others for the outcome.

Note that the first border to cross, taken in the first step, is thinner than the border for upward movement across the first horizontal transition (Step 2). Here, we move into the unstructured zone (or bypass it altogether depending on the inherent teaching style of the instructor). It is not suggested that students are allowed to proceed through this zone with no structure. Rather, it is suggested that the instructor have a structured plan to immerse students once more into higher order thinking skill development with even more burden on the student to take control of the learning experience. When students graduate, the employer will not provide a recipe for solving problems in different scenarios. Students need this type of practice while they are still students. If it is possible to engage students in real business, governmental, or higher education projects, they will gain valuable experience during the formative years and will need less supervision later when they are actively involved in the work force.

Often, it makes sense to stop at this step and reflect and become more comfortable in the environment before moving on to the next stage. To take the last step (Step 3) in this scenario, the student is at the higher level of thinking skills, there is less structure to the teaching environment and the move is into online and perhaps real time teaching modes. The move to online education requires additional preparation. There are many course management tools (e.g., WebCT, BlackBoard, eCollege) to facilitate this transition (Foreman \& Widmayer, 2002). Without an understanding of the impact of crossing this next border, failure can ensue (Hara \& Kling, 1999).

\section{Advanced Learning Style and Teaching Style: Crossing the Border in the Middle (Figure 3, "Stepladder")}

Moving along the stepladder (Figure 3) path provides a slightly different scenario than the one in Figure 2. This environment is more typical of the one found when teaching adult learners. Many students involved in distance education are adult learners either making a career change or enhancing their educational background with additional credentials. These students already have a good deal of knowledge about attacking unstructured problems. They are used to working as part of a team, changing requirements midstream, and doing more of the synthesis and evaluation work required of higher level learning skills.

Teaching adult learners is a challenge for instructors (Richardson, 1994). The students often have some of their own agendas; their learning styles and experiential experiences can be quite varied. The one size fits all approach that is more easily facilitated in a more structured environment does not work as well in this situation. The instructor needs to be adaptable, provide challenging assignments, and provide an open dialog as this path is traversed.

Step 1 in Figure 3 first involves the instructor moving the course into this more unstructured environment. This means team projects and other more open ended assignments. The instructor serves as a facilitator or guide as opposed to the traditional role of teacher. Like academic administrators, faculty must learn to show less control at first so as to allow students to uncover and discover the factors needed to resolve problems and exercise creativity and innovation (DeMichiell \& Ryba, 1997). There are still lectures, but the lectures border more on discussions where the students can contribute valuable pieces of their experiences into the educational milieu. 
FIGURE 3

\section{Advanced Learning Style and Teaching Style \\ Crossing the border in the middle}

(Stepladder)

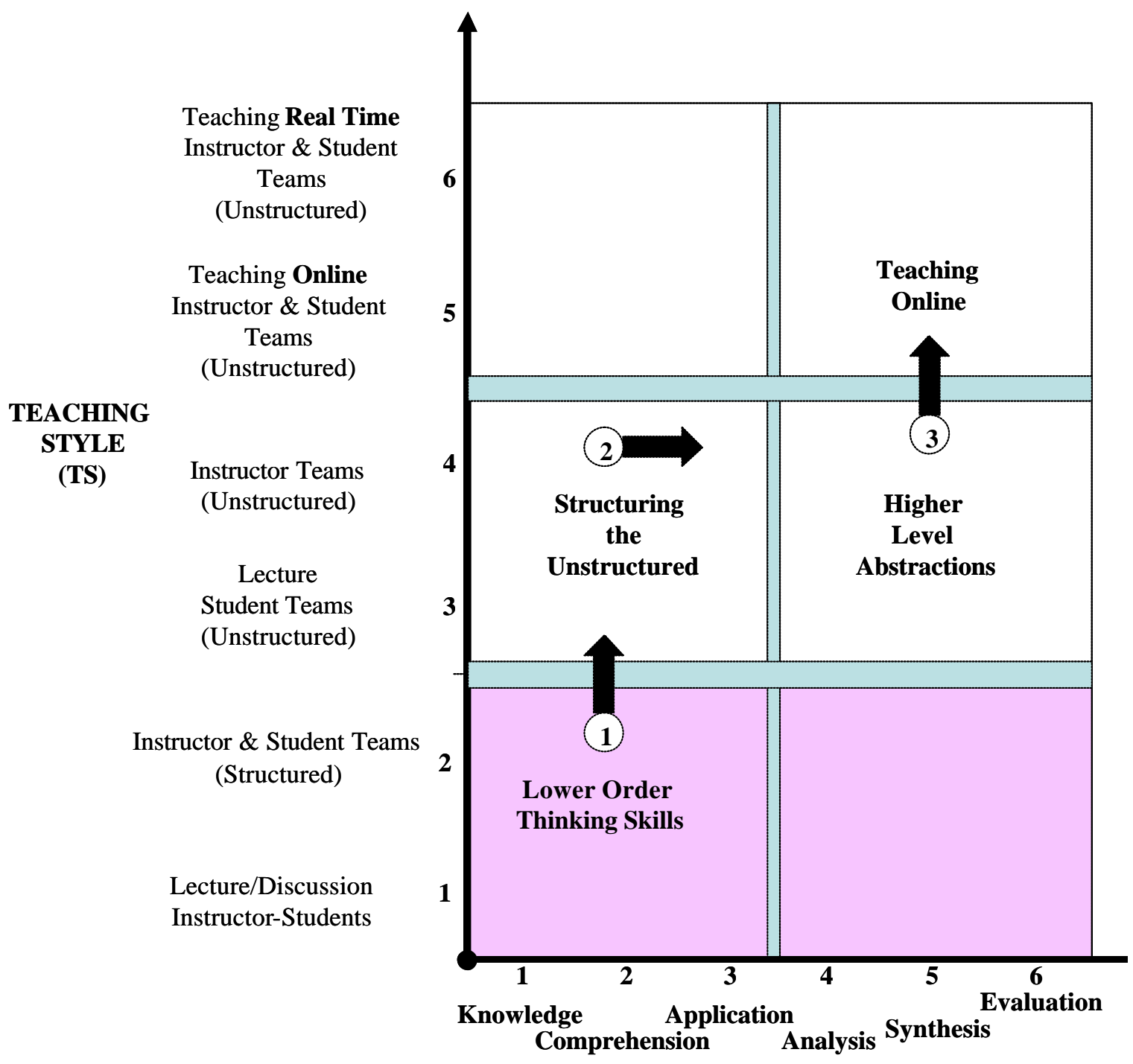

LEARNING (THINKING) SKILLS (LS)

[Bloom's Taxonomy]

Making the second step is crossing the narrower border. Because we are dealing with adult students, this step can be almost painless. Adult students are often already working at the higher level. These students usually have a large enough knowledge base that makes transition relatively easy. Even for the student changing careers, their background is often broad enough that they just need a brief introduction to the terminology and syntactic details of the new field, but they can easily apply their existing knowledge to create and build learning metaphors and reuse other semantic knowledge pieces to facilitate the learning process.

In this model, the last step (Step 3) is the bump-up. This involves crossing one of the wider borders which is a challenge for both instructor and learner. It needs to be done as a partnership or people can be 
left behind. The instructor has to know that the student has truly mastered the material and is comfortable working in the unstructured environment before the conventions and tools found in traditional educational arenas are removed. For instance, there may be limited face-to-face contact. The learner can feel more isolated. This step can succeed if a true learning community is built (Paloff \& Pratt, 1999). To create the learning community requires work on the part of the instructor and the students. Easy and frequent communication must be an integral part of the system (Dringus, 2000; Hara \& Kling, 1999; Leonard \& Guha, 2001).

\section{Teaching Style Changes: Crossing the Border at the Top (Figure 4, “Up and Over")}

The up and over path (Figure 4) is probably the hardest road to take and works best for the most experienced teacher. The steps cross the two wider borders first and then the narrow border. Again, it is possible to never get to the top and stop deliberately or get stuck along the way. For this path, Step 1 involves

FIGURE 4

Teaching Style Changes

Crossing the border at the top

(Up and Over)

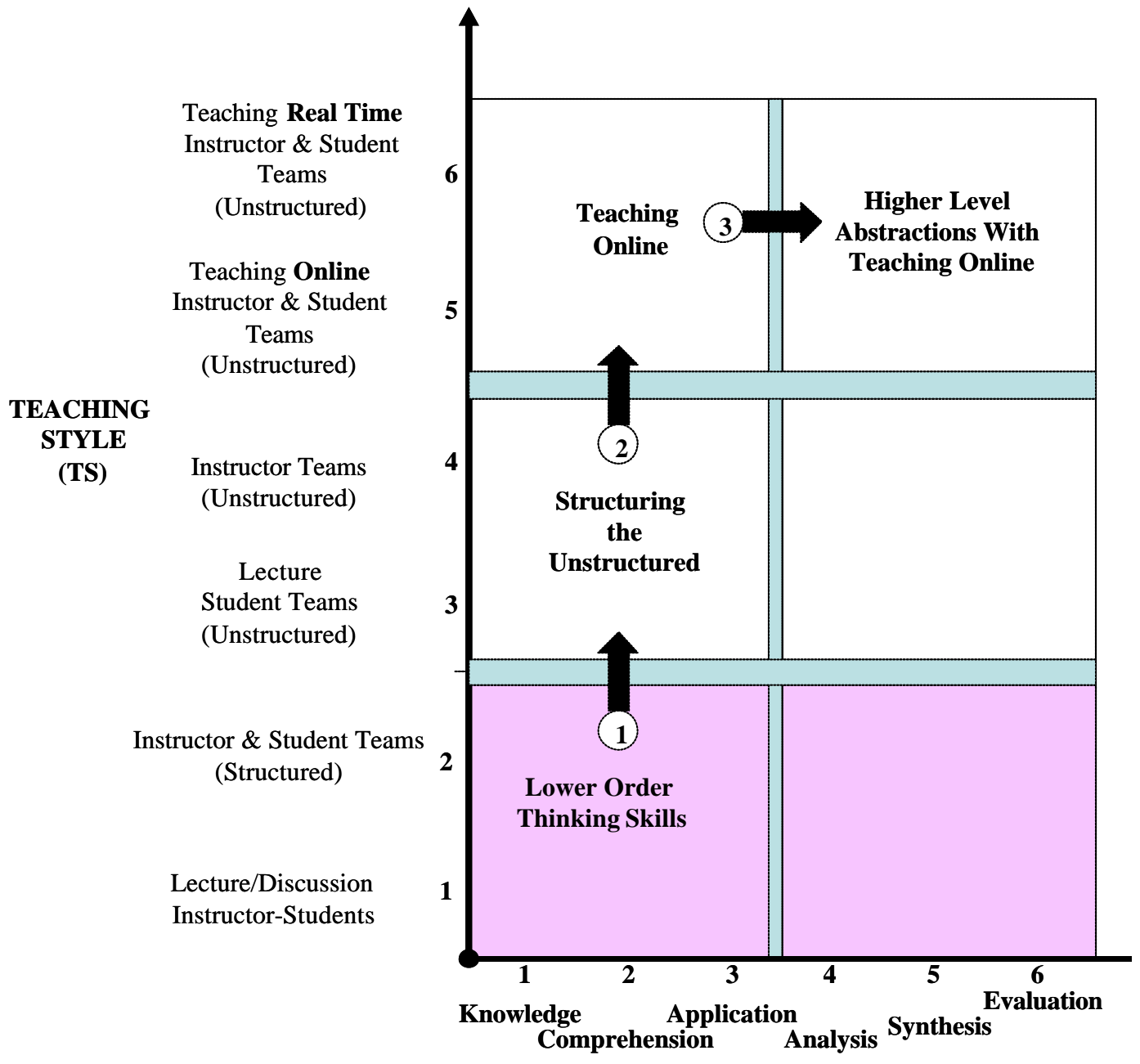

LEARNING (THINKING) SKILLS (LS)

[Bloom's Taxonomy] 
the instructor moving from the structured to the unstructured arena. This is not too difficult for an experienced instructor with an abundance of teaching experience. He or she has tried various approaches to teaching over time and knows what works best for his or her own style. The thinking skills required of the student is at a lower level, so creating lectures, discussions, and assignments are easy to manage, the answers are more clear-cut, and learning proceeds at a reasonable pace.

Taking the next step and moving to the top of the teaching style hierarchy can be a big jump for the instructor and student. Both may be moving into a foreign environment with new and unfamiliar methods of communication. Learning to use the technology itself can be part of the problem (Ellis \& Cohen, 2001). Having a good course management system can help ease this transition (Foreman \& Widmayer, 2002). Again the lower level learning skills seem to adapt well to the course management system artifacts and with some assistance, this can flow quite well. Accountability, empowerment, and project implementation are key issues as instructors move along Figure 4 into the unstructured zone.

The last step (Step 3) puts more burden on the student. This is where the narrow border is crossed into the higher level learning skills. An experienced teacher would already be familiar with these skills and

FIGURE 5

Instructor Issues

(Over and Up)

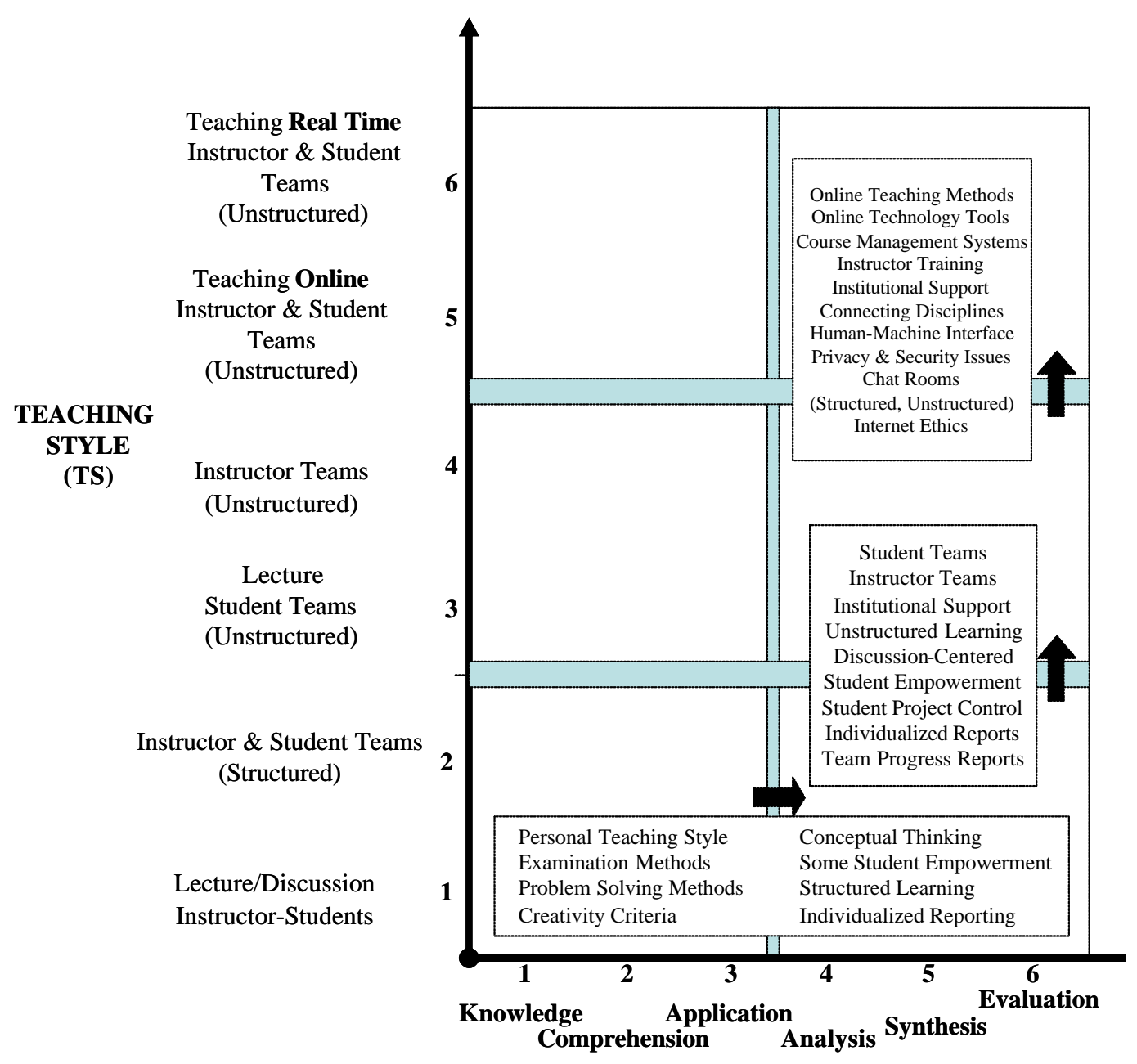

LEARNING SKILLS (LS)

[Bloom's Taxonomy] 
know appropriate exercises and assignments to teach at this level effectively. Both the instructor and student are already immersed in the online, unstructured environment. This leaves the onus on the student to make the transition to the higher level cognitive skills.

\section{Guidelines}

Figures 5, 6, and 7 show a list of hints and guidelines to aid the transitions for each of the three paths discussed in the Transitioning to Online Learning section. . These practical guidelines are presented from the instructor's viewpoint and should help new and experienced teachers considering the online teaching mode.

FIGURE 6

Instructor Issues

(Stepladder)

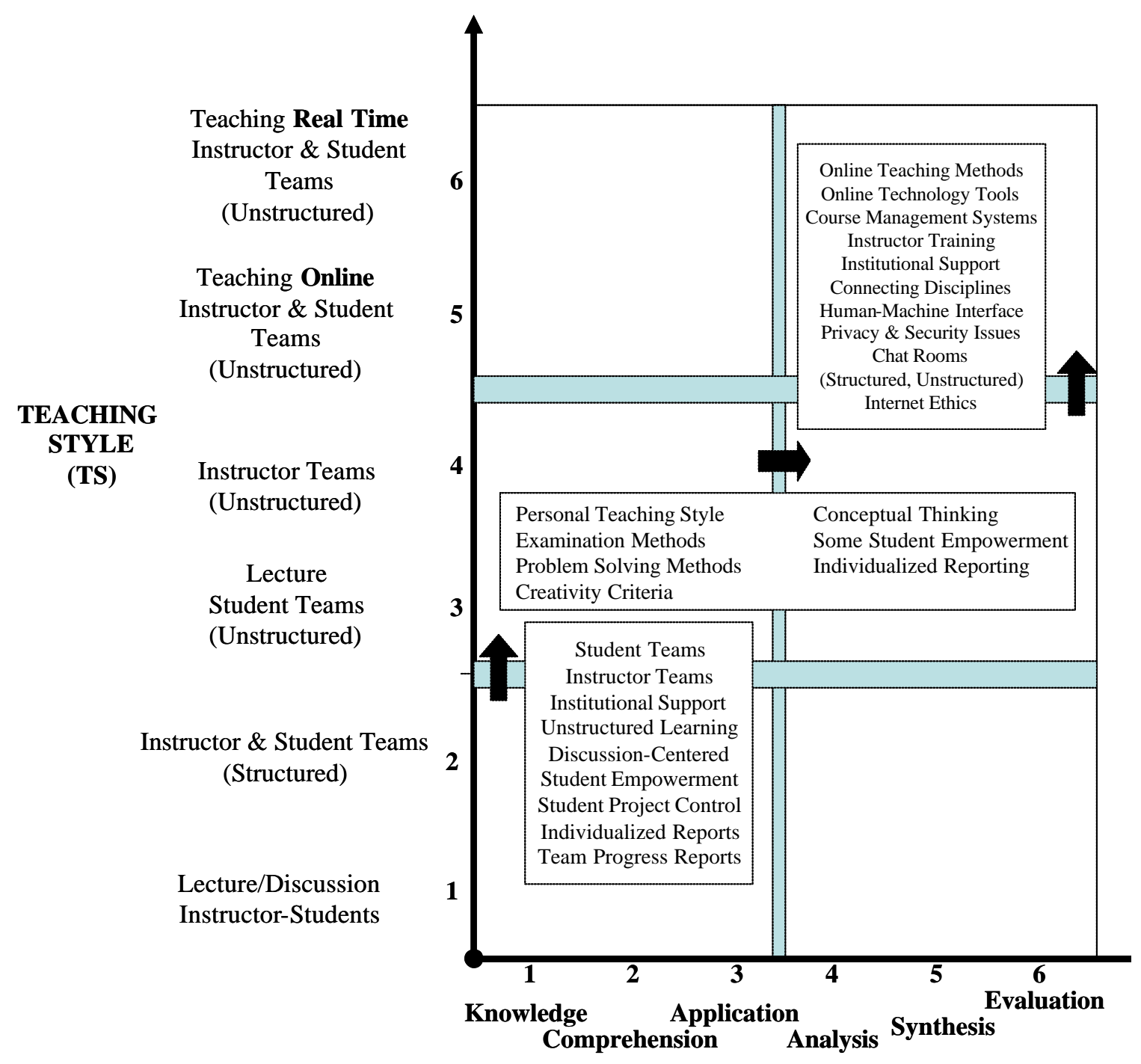

LEARNING SKILLS (LS)

[Bloom's Taxonomy] 
FIGURE 7

Instructor Issues

(Up and Over)

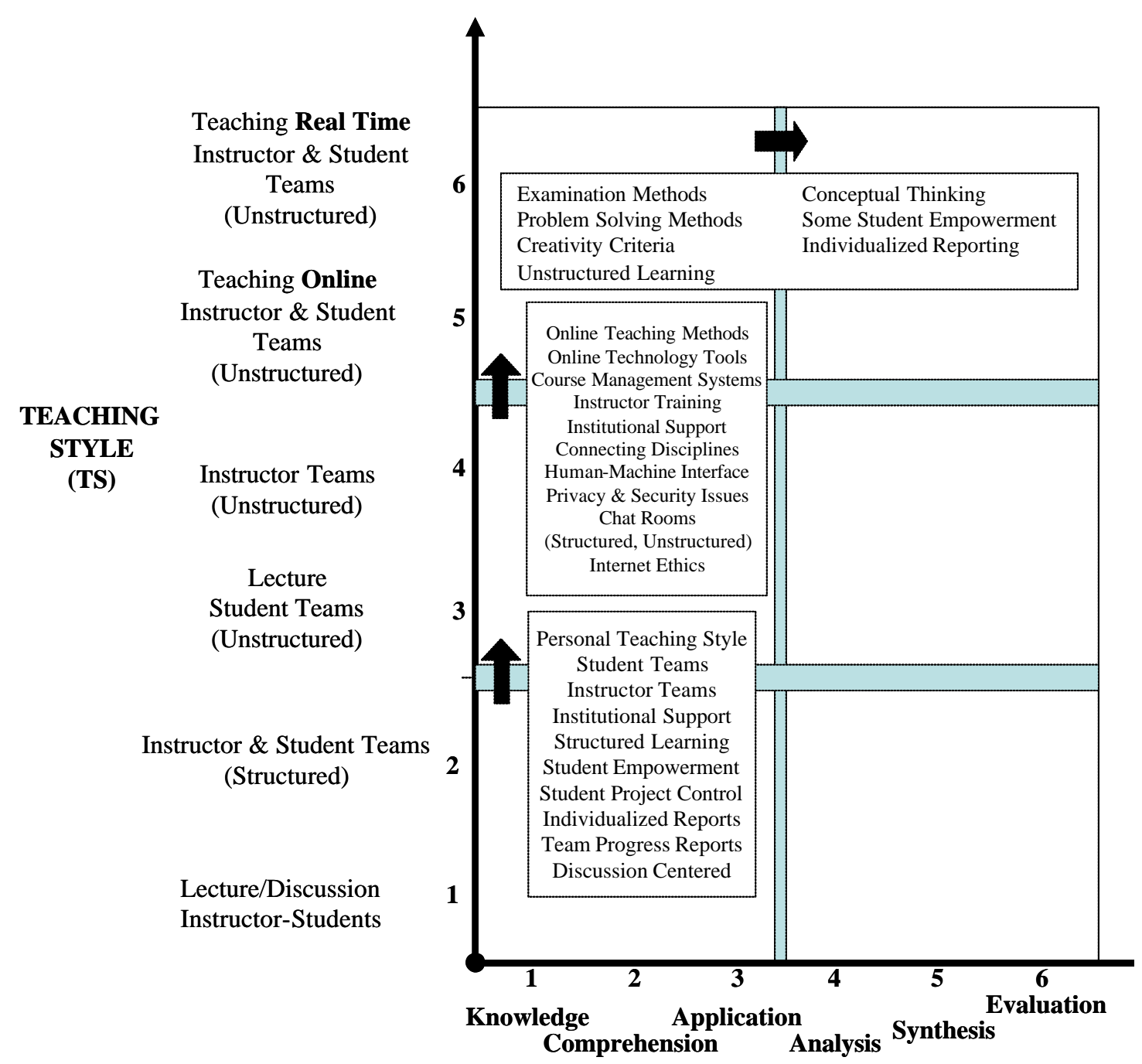

LEARNING SKILLS (LS)

[Bloom's Taxonomy]

\section{Conclusion}

This paper presents a theoretical framework for instructors as they attempt to move their teaching approaches and styles into an online environment. Several paths are provided that can be taken to facilitate this transition. The framework provides places where faculty can purposely or unintentionally stop along the way to reexamine their objectives and determine whether or not the next step is feasible. Differing requirements and expectations of both faculty and students are discussed as they contemplate or decide to make the transition to online learning.

With the heavy emphasis on moving to active learning approaches, inclusion of non-technical factors as an integral part of the learning process, and online learning, a need to establish some type of theoretical framework is indicated. Education, business, government, and other training facilities require guidance to make this important transition to the online environment. We are already starting to observe the fall- 
out of early ad-hoc attempts at this process. The attitude is changing from one of being a "no-brainer" to fill up online courses and increase enrollments to realizing the importance of careful planning and sound pedagogy to allow this new format to succeed.

History documents hundreds of years of experience teaching in the traditional method. That method has been honed and polished through the generations, yet it still is not effective for all learners. Being sensitive and aware of the needs of international students should be integrated into the teaching philosophy. Interacting with a global population provides unique perspectives not possible in a traditional classroom setting. Taking on a new method of teaching with untried and perhaps unrealistic expectations will certainly fail unless a solid framework is established. This research develops that framework and indicates practical ways for faculty at all levels to examine the tradeoffs in moving to the online environment.

\section{Research Notes}

\section{Block A: Lower left corner of Figure 1 (Traditional Teaching, Lower Skills Level)}

Traditional teaching experience of authors spanning forty years and includes instruction for undergraduates in physical sciences, engineering, computer science, management, organizational behavior, and management information systems. At this lower level of instruction, all traditional methods of teaching employed (lecture, demonstration and laboratory work, application exercises, and comprehension testing). Some very structured student team activity required. Extensive student feedback data on all courses. Manning, Cohen, DeMichiell (1962-present).

\section{Block B: Middle (Team Teaching, Lower Skills Level)}

1. Demonstration of student teams and instructor teams as they converge on company problems at Sikorsky Aircraft, Stratford, CT. Collection of specific data on each stage of structured process of final machine shop inspection for process control improvement. Required strong team organization and performance in actual operating environment. Oral and written reports to both university and corporate executives. Stressed need for interdisciplinary team approach using both structured and unstructured problem-solving methods and accountability for performance results. DeMichiell and Keenan (Summer 1994).

2. Unpublished professional development keynote presentation at AACSB workshop, San Diego, CA September 1997 on integrating the curriculum. Interdisciplinary approaches with new teaching methods. Report on Fairfield University's special program on team-teaching across departmental boundaries. Assistance and participation from General Electric Capital and other businesses. AACSB initiatives implemented successfully from 1994-1997. Ryba, DeMichiell, and Ducoffe (1997).

3. Unpublished university project work for the City of Bridgeport, CT highlighting the difficulty of incorporating change in the public sector. Student teams provided role models in city government from whom they collect data on process of government. Unstructured approach to learning about geographic information systems and all the data needed to make it work. Instructor teams. Resulted in new operational process for zoning and in design of procurement contract for city to proceed with full system. DeMichiell and Keenan (1998).

\section{Block C: Upper left corner (Online Team Teaching, Lower Skills Level)}

1. Team teaching effort applied to Multimedia Systems course. Definition of teaching responsibilities both for face to face portion and online portion. Activities presented at ACM SIGMM workshop in 1999. Cohen and Salazar (1998).

2. Combined traditional teaching experiences with the online team environment in Human Computer Interaction course. Teaching online required definition of instructor responsibilities, splitting of student population, clear demarcation of reporting structure. Evaluations included the class content as a whole and each individual instructor as well. Coordination of synchronous chat sessions throughout the term. Students obtain different perspectives, opportunity to see team effort at work. Manning and Cohen (2000 - present)

3. Mentoring to undergraduate faculty migrating into online teaching environment. Provided workshops and one on one mentoring. Cohen (2000-2001)

\section{Block D: Lower right corner (Traditional Teaching, Higher Skills Level)}

1. Added international dimension to this category as well as exercising analysis, synthesis, and evaluation to thinking skill set. Collected data by extensive interviews with staff at: BMS Ireland, Vistakon (Johnson \& Johnson), Shannon Economic Development Agency, Trinity College, Irish Government, GE Capital, University of Limerick, Euro- 
pean Foundation for the Betterment of Life and Work, Citibank, and Forbairt Innovation Park. Promoted higher thinking skills in structured environments. DeMichiell and Keenan (June, 1998).

2. Added international dimension to this category as well as higher order thinking skills. Humanitarian effort by World Association for Case Study Research and Application (WACRA) to move Czechoslovakia from forty years of communism to a free market economy. Intensive one-week program for top academicians, politicians, and business leaders focused on higher skills of creativity and innovation. Collection of data, including video, to capture problems and issues and for later development of model for classroom learning: moving from a pedantic and stagnant learning system to an action-oriented one using higher order thinking skills. Klein, DeMichiell, and others (October 1990).

3. Project work with People's Bank, Bridgeport, CT with corporate teams collecting extensive data on various bank activities prior to conducting business seminar. Approach to develop seminar topics emphasizing higher order learning skills. Interviews with key executive leaders. Deliverance of seminar by instructor teams. Creation and evaluation of new methodology by project teams and those using the system. Wysocki and DeMichiell (Summer 1996).

\section{Block E. Middle right (Team Teaching, Higher Skills Level)}

1. Several projects with People's Bank, Bridgeport, CT emphasizing team teaching in a structured environment with unstructured tools and techniques. Instructor teams of academicians and client operating personnel collected data from workers before, during, and after seminars. Objective to enable client to stay focused on higher order thinking skills and provide innovative solutions to move the company strategically and operationally. IT entrenched, but these team projects paved the way for IT deployment for distance learning approaches. Manning and DeMichiell (1995-1999).

2. Organizational and Personnel Management Department, Industrial College of the Armed Forces, Washington, DC. Teaming was the solution to the problem of frequent turnover of military faculty. Worked so well that all courses were taught in teams, even if experience levels did not mandate. Manning and others (1989-1991).

3. Implementation of total quality management initiatives (TQM) at Coast Guard Training Center, Petaluma, CA. Interdepartmental candidates traveled to contractor site for training. Resulting training cascaded down through the organization. Manning and others (1991-1993).

\section{Block F. Upper right corner (Online Team Teaching, Higher Skills Level)}

1. Online course, team taught at Fairfield University as pilot program for executive MBA students. One half on-site with students present and other half taught online with both instructors contributing on continuous basis. Several teaching methods used including onsite experiential and workshop activity and scheduled and unscheduled online chat sessions. Feedback from students throughout experience indicates the combination of onsite and offsite activities are conducive to more learning with student convenience. DeMichiell and Manning (1999-2000).

2. Online masters and doctoral courses. Students get to see conflict resolution in real time and see inside view of team effort as well as the outside presentation. Important to establish credibility, confidence, and fairness. Establishment and creation of shared grading rubrics. Important to establish division of labor, several theoretical models to choose from. Issue of ownership of online course materials. Understanding the time clock with various stakeholders (faculty and student). Issues of online and real time, limited time for reflection. Manning and Cohen (2000-present)

\section{References}

Barajas, M. (2002). Restructuring higher education institutions in Europe: The case of virtual learning environments. Interactive Educational Multimedia, 5, 1-28.

Berge, Z. (2000). A tangled web indeed: The difficulty of developing a research agenda for distance education. DEOSNEWS, $11: 10,2-30$.

Bloom, B. S. (Ed.). (1956). Taxonomy of educational objectives, Vol.1: The cognitive domain. New York, NY: McKay.

Boisjoly, R. \& DeMichiell, R. (1995). A business outcome with and international component: A new workplace dictates new learning experiences. World Association for Case Method Research \& Application (WACRA) Annual Conference Proceedings. Boston.

Buckley, Francis J. (2000) Team teaching: what, why, and how? Thousand Oaks, CA: Sage Publications .

Cohen, M. S. \& Ellis T. J. (2001). Teaching technology in an online, distance education environment. Proceedings: IEEE Frontiers in Education Conference, Reno, NV, T1F-1-T1F-6. 
DeMichiell, R. \& Manning, R. (2002). Entrepreneurial thinking for case study application: a self-assessment approach. In H. Klein (Ed.), Interactive Teaching and Learning in a Global Context. World Association for Case Method Research \& Application (WACRA), Boston, 119-126.

DeMichiell, R. \& Ryba, W. (1997). Real heroes need less control: dawn of a new breed of educator. Journal of Education for Business, 72:5.

Dringus, L.P. (2000). Towards active online learning. A dramatic shift in perspective for learners. The Internet and Higher Education, 2:4, 189-195.

Ellis, T.J. \& Cohen, M.S. (2001). Enhancing distance learning with multimedia: a win-win? Twelfth International Conference on College Teaching and Learning, 59-66.

Foreman, J. \& Widmayer, S. (2002). How on-line course management systems affect the course. Journal of Interactive Instruction Development, 13:2, 16-29.

Hanna, D.E. (1998). Higher education in an era of digital competition: emerging organizational methods. Journal of Asynchronous Learning Networks, 2:1. Retrieved September 18, 2002 from http://www.aln.org/alnweb/journal/vol2_issue1/hanna.htm

Hara, N. \& Kling, R. (1999). Students frustration with a web-based distance education course. First Monday, 4:12 Retrieved February 5, 2003 from http://www.firstmonday.dk/issues/issue4_12/hara/

Harrison, N. \& Bergen, C. (2000). Some design strategies for developing an online course. Educational Technology, 40:1, 57-60.

Keyter, C. (2002). Institutional open and distance learning collaboration in Namibia. Staff and Educational Development International, 6(3), 261-276.

Leonard, J. \& Guha, S. (2001). Education at the crossroads: online teaching and students' perspectives on distance learning. Journal of Research on Technology in Education, 34:1, 51-58.

Merryfield, M. (2002). The difference a global educator can make. Educational Leadership, 60(2), 18-21.

Paloff, R. M. \& Pratt, K. (1999). Building learning communities in cyberspace: effective strategies for the online classroom. San Francisco, CA: Jossey Bass.

Perraton, H. (2000). Rethinking the research agenda. International Review of Research in Open and Distance Learning, 1:1.

Richardson, J.T.E. (1994). Mature students in higher education: a literature survey on approaches to studying. Studies in Higher Education, 19:3, 309-325.

Twigg, C. A. (1996). Is technology a silver bullet? Educom Review, 31:2, 28-29.

\section{Biographies}

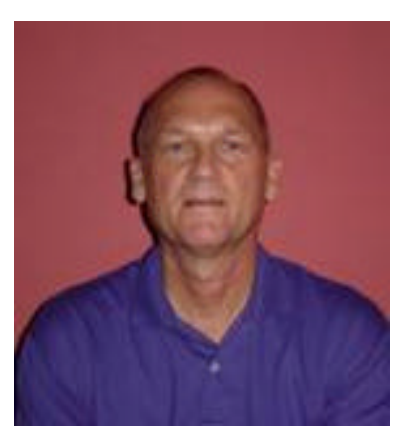

Richard D. Manning received a B.S. from the U.S. Coast Guard Academy, an M.S. from the U.S. Naval Postgraduate School, and a Ph.D. from Nova Southeastern University. He held faculty positions at Industrial College of the Armed Forces, George Washington University, and Fairfield University. He is presently Visiting Professor at the Graduate School of Computer and Information Sciences, Nova Southeastern University, Fort Lauderdale, FL. His research interests include electronic commerce, leadership, computers as persuasive technology, the relationship between technology and organizational effectiveness, and group behavior. Dr. Manning's work experience is a combination of service in the U.S. Coast Guard and training, teaching, and consulting in the civilian sector. 

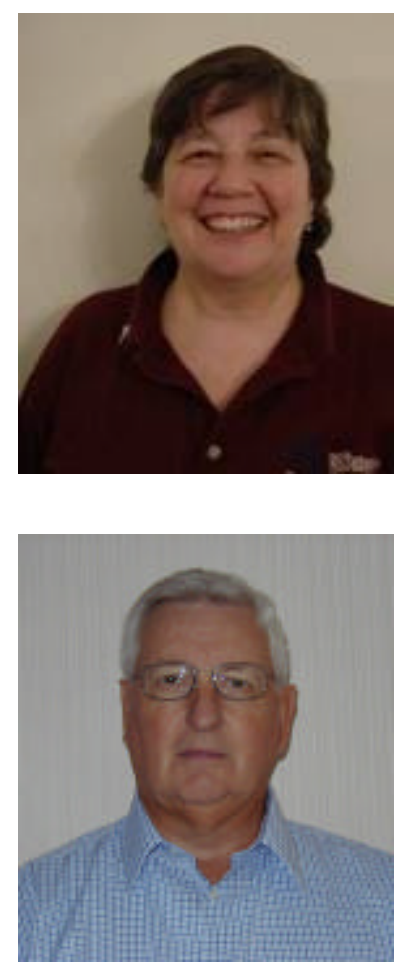

Maxine S. Cohen received a B.A. from the University of Vermont, an M.S. and a Ph.D. from the State University of New York at Binghamton. She joined Nova Southeastern University's Graduate School of Computer and Information Sciences in 1996, currently holds the rank of Associate Professor and teaches masters and doctoral level courses. Her research interests include: human-computer interaction, multimedia, and distance education. She has published and presented her work both nationally and internationally. Dr. Cohen's previous employment includes industrial experience at IBM and serving as a faculty member in the Computer Science department, in the Watson School of Engineering at the State University of New York at Binghamton.

Robert L. DeMichiell received a B.S., from the U. S. Coast Guard Academy, an M.S. and a Ph.D. from the University of Connecticut. Dr. DeMichiell was awarded Professor Emeritus from the U. S. Coast Guard Academy, New London, CT and Fairfield University, Fairfield, CT for his scholarly research and dedication to the teaching profession. Currently, he is Visiting Professor at the H. Wayne Huizenga School of Business and Entrepreneurship at Nova Southeastern University, Fort Lauderdale, FL and teaches management of information technology to doctoral students. He has presented/published one hundred articles in the past three decades. His consulting firm has conducted project work in information technology and he has presented numerous professional executive seminars. 